\title{
Impact of Annual Budgets in Economic Development of Nepal: An Econometric Analysis
}

\author{
Om Sharma, Ph.D*
}

\begin{abstract}
This paper deals with the impact of the annual budgets on the economic development process of Nepal. The epoch-making macro economic variables are introduced through the application of the econometric models of various kinds, such as linear, log-linear in single equation system, multiple forms and the Granger Causality test (1969) by applying the annual data for the period of 1974/75 to 2006/07 in current as well as constant term. The high average elasticity coefficient of manufactured GDP, GDP, GNP and PCI respectively indicate that development expenditure is highly significant in determining development. A nominal role of internal borrowing and internal revenue in the economy and the excessive dependence on foreign aid has led the country for heavy debt service obligations every years forcing for additional tax burden.
\end{abstract}

Keywords: Annual budget, economic development, impact, econometric analysis, Nepal.

\section{INTRODUCTION}

Development refers to the process of change which brings improvement in the quality of life or, it implies to the social and economic transformation through a dynamic process which often follows a well ordered sequence. However, south-east Asian countries have been searching to overcome the serious obstacles; economies are facing difficult challenges and are still in trap of poverty, unemployment, politico-economic instability, racial discrimination and gender inequality. Furthermore, uncontrolled population growth has turned the process of economic development into a precarious situation.

Dichotomized of the economic world- on the basis of social and economic conditions- developing economies as could not successfully apply modern technology and knowledge, so are still far behind in the process of development. In fact, endeavors made for are at unconvincing degree to overcome the hurdles and are suffering from low productivity, unsolved high unemployment, inequality, foreign dependence and other critical issues. The operation of annual budget however plays a prominent role for accelerating the rate of economic development of a country; attempts of the Nepal government are in vain.

\footnotetext{
* Dr. Sharma is Professor of Economics, Prithvi Narayan Campus, T.U., Pokhara
} 
The application of privatization and the liberalization policies has however, facilitated the private sectors, but are performing in cartel which lacks proper investment and entrepreneurship. Having with the per capita income of only US\$ 621 (MOF, 2013), Nepal's large proportion of population still remains below to the poverty line with high rate of inflation. To overcome these problems a sound budget is essential which clearly reflects the annual plans, programs and strategies of the government. The government invariably assumes a development role; besides of allocate and distributive, in recent years, the stabilization and adjustment have remained at the top of the policy agenda.

Deficient in basic infrastructure, and with political confusion, Nepal has given priority to building the physical infrastructure so as to spread the gains and linkages of the development strategy within the country, to integrate domestic markets and above all, to speed up rural development. The need for basic infrastructure is also justified for diversifying the economy and its export base which tends to be narrow and consists of a few primary and manufactured products only.

Given such circumstances, poverty alleviation is a major concern. The problem of poverty is seen in the broader context of rural urban imbalance, incompatibility between development intervention and environmental capacity, conflicts over the allocation of expenditures between economic and social sectors, and above all the widening gap between resources and expenditures. These imbalances need to be corrected, with their measures which can increase the productive capacity of the economy.

With the advent of the democratic political system in 1951A.D the budgetary system as applied by the first elected government in $1958 / 59$ is the first scientific budget. The regular expenditure and development expenditure consist of General Administration and Constitutional Bodies, Economic Administration and Planning, Social Services, Economic Services, Communication, Transport, Electricity, Other Economic Services and Miscellaneous.

The average annual growth rate of development budget is less compared to the regular budget during the past three decades. The increasing trend of regular expenditures on unproductive sectors and the decreasing trend of development expenditures indicate the minimization of the pace of development. Budget, however, became more significant in managing government finance, the contemplation over the status and effectiveness of budgetary system of the government increased specially after the political change of 1990. Increasing challenges encountered in relation to the rising expectations of people have prompted the government to become serious as to the means and the use of the scarce resources in a more organized and effective manner (Sharma, 1999).

Presently, government budget is much more than a statement of income and expenditure of public authorities- a reflection of not only taxation and public expenditure policy, but also of a plan for future course of action which but in thousand ways go to the root of prosperity of individuals and relation of classes, and the strength of nation. Though budget is a program for future action and is generally framed for a year, it presents a picture of the details of expenditure, taxation and borrowings for three consecutive years (Lekhi, 2006 : 362). Budget, as an important policy document, has become a principal instrument of resource mobilization and allocation. 
Impact of Annual Budgets in Economic Development of ..../3

Nepal, an agro-based economy, contributes 36 percent of GDP at real prices in FY 2006/'07 (MoF; 2006/'07). The growth rate of GDP stood at a meager 3.3 percent in FY 2005/'06 (MoF; 2006/'07). Rather than the geographical rigidity, open boarder and landlocked as major bottleneck perceived earlier, more politically orientation instead of development is the central point to be addressed by now that led to increase poverty, unemployment. Educational backwardness, traditional culture and orthodoxy religious beliefs insisted in the population growth. As a result, each budget of Nepal experienced continuous failure in delivering the expected result.

Fiscal management has been found particularly weak and disorder. Economic instability is experienced largely through centralized expenses, although public spending presently averages at around 18 per cent of GDP. A single budget cannot solve obviously all the existing socio-economic problems at once. But the budget of different periods may certainly be considered as the necessary momentum and appropriate vision towards achieving the objectives or goals in a sequential order for long range planning. The private sector can certainly play a significant role for economic development but intended for benefits.

The government budgetary operation may be one of the panaceas for economic growth. The effectiveness of the budget could be measured through the economic indicators such as GDP growth, price stability, employment generation, per capita income, socio-economic infrastructure development, transport, communication, health services, energy development, improved domestic resource mobilization and reduced dependence on foreign finance, balance of payment improvements, poverty reduction, better law and security environments, fiscal welfare improvement etc.

Several annual budgets are undertaken under different political systems with specific priorities and strategies that have embodied resource mobilization, expenditure management and fiscal structure aiming for full utilization of resources which could not match with rigidities. The attempts to increase the quality of life of the people seem to be mere cipher and increase in the rate of economic growth has remained insignificant nevertheless high potentialities of development. In this sense, it would be the important issue and useful to analyze the types of objectives, policies and targets as included in the budgets and their actual outcomes so that the differences between the investment and outcome could be identified with some beneficial measures.

Concentrating on to the gap between the targets and achievements in Nepal's budgetary system, this study tries to analyze the existing scenario, constraints and trends of the government budgets with remedial measures. Accordingly, this study attempts to look the policy framework of budgets of the past along with their main fiscal achievements. This study attempts to seek the reasons behind the failure of every budgetary policy, which in fact, is a cry off issue among the Nepalese policy maker, planner, experts and social scientists.

The specific objectives of this study are : a) To analyze the trend of annual budget and economic development of Nepal, b) To analyze the effects of annual budget on economic development in Nepal and c) To draw suggestions of the budgetary policy on the basis of the findings. 


\section{REVIEW OF LITERATURE}

Right from Adam Smith, down to Marx, and Keynes, the study of economic development has attracted mainly the problems of static nature of development. It is however, the $20^{\text {th }}$ century economists who started to give attention towards analyzing the problems and formulating new theories and models that concentrated on the capital formation in promoting economic development.

The concept of economic development is indefinable universally. It is the result of secular changes in long run. As time changes the indicators also change. However, various development indicators have been put forward to get idea about the state of development. Earlier concept of Gross National Product (GNP) as an indicator economic development is changed through the supposition of NI as a reliable measure by Kuznets (1955), Meier and Baldwin (1960). Higgins (1999), Leibebstein (1957), Lewis (1961) and Jacob (1977) considered PCI as a basic indicator. Human development Index (HDI and emphasis upon non-economic social indicators like quality of life are the latest accepted development indices. In against of Mercantilists' undue emphasis to precious metals, Physiocrats' evolved the doctrine of agriculture as the sole source of all wealth and others as sterile. To Smith (1976) national production is an indicator of economic development and viewed profit is the main factor and Mill's (1848) cooperative society (Hajela; 2001). However, the emphasis on GDP as an index of economic development is given relating to the experience of the developing countries which differ radically from the socio-economic set up of the developed countries. Meier (1963) and Baron (1957) have accepted per-capita income as the process of economic development.

Besides these indicators, the direct provision of basic needs approach (health, education, food, water, sanitation and housing) affects poverty in a shorter period and with fewer monetary resources than GNP and per capita income strategy. Hicks and Streeten (1979) consider six social indicators for basic needs such as life expectancy at birth, literacy signifying primary school, enrollment as per cent of population, calorie supply per head, infant mortality and percentage of population with access to portable water, Infant mortality and percentage of population with access to sanitation. But the limitations associated with the social indicators as the measure of economic development, problems arise in constructing a composite index based on a rational weighting system. Morris D. Morris constructed a composite physical quality of life index (PQLI) in 1979 relating to 23 developing countries and combines three component indicators of infant mortality, life expectancy at age one and basic literacy at age 15 to measure performance in meeting the most basic needs of the people. This index represents a wide range of indicators such as health education, drinking water, nutrition and sanitation. The PQLI is calculated by averaging the three indicators giving equal weight to each (Todaro; 1997). Though, the index has been criticized for using arbitrary weights, can be applied to identify particular reasons of under-development and societal exclusion. Similarly, in 1990 the UNDP has presented the measurement of human development in terms of a Human Development Index (HDI), a composite index of three social indicators: life expectancy, adult literacy and years of schooling along with real GDP per capita. Likewise, Goldstein takes only infant mortality as indicator of basic needs to construct "The plateau curve Index". Hagon uses about eighteen variables in the measurement. Thus, problem arises in constructing a composite index based on a rational weighting system. However, if each country chooses its own list of social indicators and assigns rational weight to them, the basic needs strategy seems better than GNP, PCI and other welfare and social indicator of economic development. As these social 
Impact of Annual Budgets in Economic Development of ..../5

indicators are dependent on value judgment, economists and UN organization use per capita the measure of economic development.

Concerning with Nepalese context Singh (1976) derives that the expenditure /GDP ratio has increased but the growth rate of regular expenditure was comparatively slower. Khanal (1988) draws some policy implications on short term economic stabilization and long term development. Sharma and et al (1988) measures the elasticity coefficient for all tax heading i.e. direct tax, indirect tax and land tax which remained inelastic. The actual performance for collecting the tax revenue shows a downward trend with negative elasticity coefficient of land tax. Therefore, it has been felt that Nepalese budget has been working in a perpetual aura of financial crisis resulting in excess dependency on external assistance due to inefficient and under utilization of available funds. Actually, the public expenditure in Nepal grew steady and perceptible shift in the composition of expenditures towards current transfers and subsidies, interest and grant payment and all have higher growth rates then other heads of expenditures (Sharma, 1999). That is why Pyakuryal (2004) asserts that the economy has lost its productive capacity to respond to the sustained growth. Bhattrai (2007) too finds the positive effects of aid to both development and non-development expenditures in the long run but non development expenditure is stronger. There remains so the possibility of aid fungibility. In fact, aid is given in the form of technical assistance for improving tax administration and the efficiency of the tax system. Hence, it may be said that 'the manner in which government budgets can affect the economy is varied' (Chaudhary, 1996)

\section{DATA AND METHODS}

In this study, time series data have been applied for the period of $1974 /{ }^{\prime} 75$ to $2006 /{ }^{\prime} 07$. The secondary data used in this study have been collected by careful examination of reports published by the concerned authorities such as NRB, MOF, various budget speeches of Nepal government, books and journals. The trend functions in linear, quadratic and compound forms are shown to the time series data which may be stated below.

$$
\begin{aligned}
& Y_{i}=a+b(t) \\
& Y_{i}=a+b(t)+c(t)^{2} \\
& Y_{i}=a b^{(t)}
\end{aligned}
$$

The simple linear and log linear form (nominal and real prices) to examine the effects of aggregate development and aggregate regular expenditure on various development indices such as agriculture gross domestic product (GDPa $a_{\mathrm{g}}$, manufacturing gross domestic (GDPm), GDP, PCI, and GNP. The models may be expressed as:

$$
\begin{aligned}
& Y_{t}=\alpha_{0}+\alpha_{1} X_{t}+u_{i} \\
& \ln Y_{t}=\beta_{0}+\beta_{1} \ln X_{t}+u_{i} \\
& \text { Where, } \alpha_{1}>0, \beta_{1} \leq 0 r>1
\end{aligned}
$$

Effects of different sub-groups of aggregate development expenditure (SS, EAP, E.C, and M), and aggregate regular expenditure on different development indices have also been examined through the application of following linear and log linear regression models in both nominal and real prices.

$$
\mathrm{Y}_{\mathrm{t}}=\alpha_{0}+\alpha_{1} \mathrm{X}_{1}+\ldots \ldots . .+\alpha_{5} \mathrm{X}_{5}+\mathrm{u}_{\mathrm{i}}
$$

Where, $\alpha_{1}>0, \alpha_{1}>1$ 


$$
\begin{aligned}
\ln Y_{t}= & \beta_{1}+\beta_{1} \ln X_{1}+\ldots \ldots \ldots+\beta_{1} \ln X_{5}+u_{i} \\
& \text { Where, } \beta_{1}<1 \text { or } \beta_{1}>1
\end{aligned}
$$

The role of foreign aid, internal loan and internal revenue on real and nominal development and aggregate regular expenditures has also been sought through the use of multiple regression models in both linear and log-linear. For seeking remedial measures to the presence of serial correlation in the models further are regressed in the first difference form.

The Granger causality test is applied to a simple one-year lag between aggregate development expenditure and the development indices such as GDPag, GDPm, GDP, PCI, and GNP. The functional equations for this purpose are:

$$
\begin{aligned}
& \mathrm{GDP}_{\mathrm{t}}=\alpha+\beta \mathrm{DE}_{\mathrm{t}}+\gamma \mathrm{GDP}_{\mathrm{t}-1}+\mathrm{u}_{\mathrm{t}} \\
& \mathrm{ADE}_{\mathrm{t}}=\theta+\lambda \mathrm{GDP}_{\mathrm{t}}+\eta \mathrm{DE}_{\mathrm{t}-1}+\mathrm{u}_{\mathrm{t}}
\end{aligned}
$$

\section{PRESENTATION AND ANALYSIS OF RESULTS}

\section{Trend Analysis of Selected Development Indicators}

In a wider sense, the development expenditure occupies a crucial role for the overall economic development and is regarded as the engine for driving the economy towards the path of growth. Regular expenditure is incurred mostly on unproductive sectors like salaries and wages, loan and interest payment, wear and tear etc. This part of the study attempts to analyze the trend of selected variables of development like agricultural GDP, manufacturing GDP, Per Capita Income, GNP, GDP, and Capital Formation at nominal prices and the expenditures such as DE, RE, TE and their ratio with GDP. Trend function especially shows the persistent growth, decline or long run tendency and prediction. Trend is inference associated with stationary processes which is no longer valid if the time series are indeed realizations of non-stationary processes. The growth rates of various indicators are illustrated in the Table 1.

Table 1: Growth rates of Various Indicators (1974/75-2006/07)

\begin{tabular}{|c|c|c|c|c|c|}
\hline Equa. & Dependents & $\begin{array}{c}\text { Compound Growth } \\
\text { Rate(\%) natural1og }\end{array}$ & t-value & $\mathbf{R}^{\mathbf{2}}$ & SEE \\
\hline 1.1 & GDPag & 8.9 & 154.1 & 0.86 & 0.354 \\
\hline 1.2 & GDPm & 14.2 & 266.8 & 0.98 & 0.200 \\
\hline 1.3 & GDP & 11.8 & 248.8 & 0,96 & 0.219 \\
\hline 1.4 & GNP & 12.7 & 385.4 & 0.98 & 0.140 \\
\hline 1.5 & PCI & 9.6 & 238.9 & 0.94 & 0.228 \\
\hline 1.6 & Pop & 2.2 & 4638.8 & 0.99 & 0.011 \\
\hline 1.7 & K & 13.9 & 307.7 & 0.98 & 0.170 \\
\hline 1.8 & DE & 10.9 & 152.3 & 0.89 & 0.350 \\
\hline 1.9 & DE/GDP & -0.009 & 194.5 & 0.10 & 0.281 \\
\hline 2.1 & RE & 16.2 & 433.3 & 0.99 & 0.126 \\
\hline 2.2 & RE/GDP & 4.3 & 337.8 & 0.91 & 0.128 \\
\hline 2.3 & TE & 13.9 & 308.2 & 0.98 & 0.177 \\
\hline 2.4 & TE/GDP & 2.0 & 337.4 & 0.60 & 0.162 \\
\hline
\end{tabular}

Source: Computed on the basis of the results of trend functions. 
Impact of Annual Budgets in Economic Development of ..../7

The agricultural GDP implies the level of improvement in agricultural production. The compound growth rate of agricultural GDP remains 8.9 percent per annum during the review period. However, the nominal manufactured GDP is increasing at non-uniform rate, 14.2 per cent per annum, but is remarkable. GDP increases at the rate of 11.8 percent per annum. Nominal GNP too is increasing at nonlinear trend. The growth pattern in each year is to some extent appreciable but increase in ADE was unrealized due to civil war. In fact, the lower trade-off of Nepalese development expenditure does not perform significant role to stimulate gross domestic product similar to the derived results by Khanal (1988) during the period 1965 - 1981.

Likewise, all the nominal manufactured GDP, total GDP, GNP, PCI, capital formation, population, aggregate development expenditure, aggregate regular expenditure and total expenditure have been fitted on compound function having annual growth rate of 14.2, 11.8, 12.7, 9.6, 13.9, 2.2, 10.9, 16.2 and 13.9 percent respectively. Similarly, the DE/GDP, RE/GDP and TE/GDP ratios' growth rates seem to be, $0.009,4.3$ and 2.0 percent, respectively. Gaudel (2007) finds that the share of recurrent expenditure remains highest $(30.8 \%)$ on social services and envisages the share of capital expenditure to total expenditure as 67.8 per cent in FY 1990/91 declined to 26.67 per cent in 2004/05.

\section{The Impact of Annual Budget}

As the major purpose of this analysis is to examine relationship between the development indices and the amount of expenditure performed by the government in different headings such as development expenditure and regular expenditure, the models have been tested in various forms like linear, log-linear, first order difference form. The empirical analysis has been sought to find out the effects of development expenditure through the help of internationally accepted development indicators. In spite of some improvement in autocorrelation in first difference form the low explained percent of variation instigate for further treatment. Even though serial correlation does not persist but the low degree of association does not allow for formulating and implementing the policies in conformity with development indicators.

The empirical results derived from the application of first difference form in log linear models on nominal database justify that there is positive relationship between development expenditure and development indices. The positive sign and magnitude of the average elasticity coefficient and the high degree of association refer to the validity of the model. Except agricultural GDP, the elasticity coefficients of development expenditure is greater than unity for all development indices which implies that any increase in development expenditure leads to more than proportional increase in manufactured GDP, GDP, GNP and PCI. On the other hand, the elasticity coefficient of GDP and GNP with respect to development expenditure, seems to be more responsive $(\mathrm{e}=1.42)$. Similarly, the high average elasticity coefficient of manufactured GDP, GDP, GNP and PCI i.e. e=1.227, 1.42, 1.43 and 1.06 respectively indicate that development expenditure is highly significant in determining nominal development indices whereas the D-W values of agricultural GDP, manufactured GDP, total GDP, GNP and PCI in equations show the absence of autocorrelation after the diagnosis of remedial measure.

Furthermore, the elasticity coefficients of total GDP and GNP seem to be more responsible with respect to development expenditure i.e. $\mathrm{e}=1.39$ elicited by the positive sign and magnitude of coefficient of aforementioned development indices. Along with these satisfactory results, F statistic, the D-W statistic related with agricultural GDP and PCI lying within the acceptable regions permit to draw reliable conclusions. But regarding manufactured GDP, GDP and GNP, there persists serial correlation. 
Thus, the empirical analysis of both the nominal and real data with log linear models of first order difference expenditure contributes to raise the development indices. In the log linear regression model, it is illustrated that a unit change in development expenditure leads to increase in agriculture GDP by 1.3 percent change. It also brings change in manufactured GDP, GDP, GNP and PCI by 1.8, 1.39, 1.39 and 1.02 respectively. The increment in aforementioned development indices by more than proportionate rate imply that the government should give more consideration for making further investment on development expenditure in Nepal so as to raise agricultural GDP, manufactured GDP, GDP, GNP and PCI.

\section{Granger Causality Test}

Inappropriateness of the results of first difference form led to apply Granger Causality test. There may be reverse causation as well. The Granger causality test assumes that the information relevant to the prediction of the respective variables is contained solely in the time series data (Sharma, 2001). In this context, variables are shown to nominal as well as real data so as to find out if it is annual government development expenditure that causes an increase in the development indices, or an increase in development indices that leads to an increase in government development expenditure.

Table 2: Granger Causality Test (current \& Constant Price): 1974/075-2006/07

\begin{tabular}{|c|c|c|c|c|c|c|c|c|}
\hline Equ. & $\begin{array}{l}\text { Dep. } \\
\text { Vari. }\end{array}$ & $\boldsymbol{\alpha}$ & B & $\gamma$ & $\mathbf{R}^{2}$ & $\mathbf{F}$ & D-W & SEE \\
\hline 2.5 & GDPmt & -1023.6 & $\begin{array}{l}\text { 1.19DEt-1 } \\
(3.41)^{* * *}\end{array}$ & $\begin{array}{l}0.941 \mathrm{GDPmt}-1 . \\
(25.78)^{* * *}\end{array}$ & 0.99 & 2391.3 & 2.67 & 8742.2 \\
\hline 2.6 & DEt & 944.7 & $\begin{array}{l}\text { 9.878E03GDPmt-1. } \\
(0.96)\end{array}$ & $\begin{array}{l}0.947 \mathrm{DEt}-1 \\
(9.59) * * *\end{array}$ & 0.95 & 313.7 & 1.42 & 2462.9 \\
\hline 2.7 & $\mathrm{GDP}_{\mathrm{t}}$ & -32960.7 & $\begin{array}{l}4.214 \mathrm{DE}_{\mathrm{t}-1} \\
(3.992)^{* * *}\end{array}$ & $\begin{array}{l}0.732 \mathrm{GDP}_{\mathrm{t}-1} \\
(9.953)^{* * *}\end{array}$ & 0.974 & 571.7 & 2.47 & 25493.6 \\
\hline 2.8 & $\mathrm{DE}_{\mathrm{t}}$ & 685.4 & $\begin{array}{l}-1.01 \mathrm{E}-3 \mathrm{GDP}_{\mathrm{t}-1} \\
(-0.140)^{*}\end{array}$ & $\begin{array}{l}1.047 \mathrm{DE}_{\mathrm{t}-1} \\
(10.116)^{* * *}\end{array}$ & 0.953 & 303.9 & 1.50 & 2500.4 \\
\hline 2.9 & $\mathrm{GNP}_{\mathrm{t}}$ & 1361.1 & $\begin{array}{l}0.832 \mathrm{DE}_{\mathrm{t}-1} \\
(2.552)^{* *}\end{array}$ & $\begin{array}{l}1.036 \mathrm{GNP}_{\mathrm{t}-1} \\
(55.062)^{* * *}\end{array}$ & 0.998 & 8815.2 & 1.50 & 8404.9 \\
\hline 3.1 & $\mathrm{DE}_{\mathrm{t}}$ & 989.3 & $\begin{array}{l}7.925 \mathrm{E}-03 \mathrm{GNP}_{\mathrm{t}-1} \\
(1.466)\end{array}$ & $\begin{array}{l}0.909 \mathrm{DE}_{\mathrm{t}-1} \\
(9.707)^{* * *}\end{array}$ & 0.956 & 326.8 & 1.43 & 2415.3 \\
\hline 3.2 & $\mathrm{PCI}_{\mathrm{t}}$ & 227.9 & $\begin{array}{l}0.216 \mathrm{DE}_{\mathrm{t}-1} \\
(4.397)^{* * *}\end{array}$ & $\begin{array}{l}0.627 \mathrm{PCI}_{\mathrm{t}-1} \\
(7.341)^{* * *}\end{array}$ & 0.975 & 590.0 & 2.37 & 987.0 \\
\hline 3.3 & $\mathrm{DE}_{\mathrm{t}}$ & 703.1 & $\begin{array}{l}0.169 \mathrm{PCI}_{\mathrm{t}-1} \\
(-0.790)\end{array}$ & $\begin{array}{l}1.126 \mathrm{DE}_{\mathrm{t}-1} \\
(9.134)^{* * *}\end{array}$ & 0.954 & 310.2 & 1.66 & 2475.9 \\
\hline 3.4 & $\mathrm{RGDP}_{\mathrm{t}}$ & 2391.6 & $\begin{array}{l}1.321 \mathrm{DE}_{\mathrm{t}-1} \\
(1.683)^{*}\end{array}$ & $\begin{array}{l}0.828 G P_{\mathrm{t}-1} \\
(12.573)^{* * *}\end{array}$ & 0.913 & 157.3 & 2.02 & 3597.9 \\
\hline 3.5 & $\mathrm{RDE}_{\mathrm{t}}$ & 581.0 & $\begin{array}{l}-5.36 \mathrm{E}-03 \mathrm{GDP}_{\mathrm{t}-1} \\
(-0.862)\end{array}$ & $\begin{array}{c}0.895 \mathrm{DE}_{\mathrm{t}-1} \\
(12.123)^{* * *}\end{array}$ & 0.883 & 113.4 & 2.22 & 338.3 \\
\hline 3.6 & $\mathrm{RPCI}_{\mathrm{t}}$ & 361.7 & $\begin{array}{l}\text { 6.639E-02DE }{ }_{t-1} \\
(1.859)^{*}\end{array}$ & $\begin{array}{l}0.669 \mathrm{PCI}_{\mathrm{t}-1} \\
(6.358)^{* * *}\end{array}$ & 0.797 & 58.9 & 1.66 & 150.7 \\
\hline 3.7 & $\mathrm{RDE}_{\mathrm{t}}$ & 779.1 & $\begin{array}{l}-0.295 \mathrm{PCI}_{\mathrm{t}-1} \\
(-1.2 .67)\end{array}$ & $\begin{array}{l}0.933 \mathrm{DE}_{\mathrm{t}-1} \\
(11.790)^{* * *}\end{array}$ & 0.889 & 116.9 & 2.39 & 333.8 \\
\hline
\end{tabular}

$\left(*, * *, \&^{* * *}\right)$ refer significant at $10 \%, 5 \%$ and $1 \%$ level of significance. Parentheses refer t- values 
Impact of Annual Budgets in Economic Development of ..../9

Comparing the empirical evidence as demonstrated by the functional equations of nominal and real database included in Tables 1.2 it is clear that lag period's aggregate development expenditure $\left(\mathrm{DE}_{\mathrm{t}-1}\right)$ plays significant role to increase current GDP and PCI, similar to the results where causation leading from real agricultural GDP and manufactured GDP to aggregate development expenditure. Thus, it may be concluded from the above analysis that the lagged coefficients of aggregate development expenditure as well as manufactured GDP, GDP and PCI are significantly different from zero and so a bilateral causality is observed. The log-linear models have also been exemplified in first order difference form to the nominal and real database so as to solve autocorrelation. The results after the diagnosis of first order difference form are mentioned in the Table 3 .

Table 3: Results of Log linear models in First Order Difference Form: (1974/75-2006/07)

\begin{tabular}{|l|l|l|l|c|c|c|c|}
\hline \multirow{2}{*}{ Eq $^{\mathbf{n}}$} & \multirow{2}{*}{$\begin{array}{c}\text { Dep. } \\
\text { Vari. (Real) }\end{array}$} & \multicolumn{2}{|c|}{ InRE (constant price) } & \multicolumn{5}{c|}{ Statistics } \\
\cline { 3 - 8 } & & Constant & \multicolumn{1}{|c|}{ Coefficients } & $\mathbf{R}^{2}$ & F & DW & SEE \\
\hline 4.6 & $\operatorname{lnGDPag}$ & -0.102 & $\begin{array}{l}1.447 \\
(54.2)^{* * *}\end{array}$ & 0.990 & 2935.9 & 1.897 & $0.92 \mathrm{E}-02$ \\
& & & $\begin{array}{l}1.341 \\
(101.1)^{* * *}\end{array}$ & 0.997 & 10224.1 & 2.361 & $4.59 \mathrm{E}-02$ \\
\hline 4.7 & $\operatorname{lnGDPm}$ & $-5.73 \mathrm{E}-02$ & & & \\
\hline 4.8 & $\operatorname{lnGDP}$ & $-8.37 \mathrm{E}-02$ & $\begin{array}{l}1.515 \\
(65.7)^{* * *}\end{array}$ & 0.993 & 4316.4 & 1.906 & $8.09 \mathrm{E}-02$ \\
\hline 4.9 & $\operatorname{lnGNP}$ & $-7.79 \mathrm{E}-02$ & $\begin{array}{l}1.514 \\
(68.1)^{* * *}\end{array}$ & 0.993 & 4635.5 & 1.839 & $7.84 \mathrm{E}-02$ \\
\hline 5.1 & $\operatorname{lnPCI}$ & $-6.15 \mathrm{E}-02$ & $\begin{array}{l}1.107 \\
(60.8)^{* * *}\end{array}$ & 0.992 & 3700.8 & 1.964 & $6.03 \mathrm{E}-02$ \\
\hline
\end{tabular}

Note: Figures in (...) and asterisks confer the same meanings as explained in Table 1.2

With reference to the above results, it may be argued that an increase in regular expenditure has a positive effect on all the development indices as indicated by the positive sign and magnitude of the coefficients. Other things remaining the same, an increase of one percent regular expenditure leads to greater than proportionate increase in the development indices like agricultural GDP, manufactured GDP, GDP, GNP and PCI. Not only the explanatory powers of the models high enough; but also the coefficients are significant at 1 percent level. In addition, all other necessary statistical tests have indicated quite satisfactory results along with D-W statistic lying in the acceptable bounds. On the other hand, the elasticity coefficient of GDP and GNP with respect to regular expenditure, however, seem more responsive $(1.550>1$ and $1.554>1)$.

\section{Multiple Regression Analysis}

At this juncture, the major attempt is to be the study of the relationship between annual budget and economic growth. Since, annual budget occupies as an engine of economic growth in comparison with private domestic sector, NGOs and INGOs, an endeavor has been made to test the role of annual budget in the Nepalese economy.

For this, the development expenditure and regular expenditure at current as well as constant prices have been considered as dependent variables. Similarly, the various sectors of expenditure of development and 


\section{0 / Om Sharma}

regular expenditures such as general administration (GA), economic administration and planning (EAP), social services (SS), economic services (ES), communication (C), transportation (T), electricity (E), other economic services (OES), miscellaneous expenditure (ME) in current as well as constant prices have been taken as independent variables. Here, it is worth to mention that GA, ES, T and SS are combined together in social services (SS) and also OES is combined in EAP and their collective relation with development and regular expenditures has been extracted since multicollinearity is realized while it is exemplified in partial correlation with the development indices.

\section{Development Expenditure with its Sub-factors}

The sub factors of development expenditure exhibit quite high explanatory power of the model along with the necessary statistics except that of the miscellaneous expenditure (ME). The positive sign and magnitude of the elasticity coefficient of the model reveals that one percent change in social services (SS), electricity (E) lead to 0.67 and 0.14 percent change in development expenditure. The other independent variables have low coefficients implying the less elastic relation to development expenditure. The necessary statistics except miscellaneous expenditure (MD) are significant at 1 per cent level. The low standard error of estimate of the model and positive sign and magnitude of the coefficient of the explanatory variables demonstrate the good fit of the model. In a nutshell, the model has been provided the satisfactory result as allowed by DW statistic to draw the inferences.

Table 4: Regular Expenditure with its Sub-Factors

\begin{tabular}{|c|c|c|c|c|}
\hline Models & $\begin{array}{l}5.2 \text { Linear } \\
\text { (Nominal) }\end{array}$ & $\begin{array}{c}5.3 \text { Linear } \\
\text { (Real) }\end{array}$ & $\begin{array}{c}\text { 5.4 Log-linear } \\
\text { (Nominal }\end{array}$ & $\begin{array}{c}5.5 \text { Log-linear } \\
\text { (Real) }\end{array}$ \\
\hline Dependent Variable & $\mathrm{RE}$ & $\mathrm{RE}$ & RE & RE \\
\hline Indep. Variables & \multicolumn{4}{|c|}{ Coefficients \& t-values } \\
\hline SS & $\begin{array}{l}1.416 \\
(25.178) * * *\end{array}$ & $\begin{array}{l}1.366 \\
(21.739) * * *\end{array}$ & $\begin{array}{l}0.668 \\
(13.982) * * *\end{array}$ & $\begin{array}{l}0.598 \\
(14.56)^{* * *}\end{array}$ \\
\hline EAP & $\begin{array}{l}-3.565 \\
(-2.274) * *\end{array}$ & $\begin{array}{l}-3.780 \\
(-2.125) * *\end{array}$ & $-1.41 \mathrm{E}-05$ & $\begin{array}{l}1.412 \mathrm{E}-02 \\
(0.39)\end{array}$ \\
\hline $\mathrm{E}$ & $\begin{array}{l}-93.067 \\
(-7.993) * * *\end{array}$ & $\begin{array}{l}-67.03 \\
(-7.02)^{* * *}\end{array}$ & $\begin{array}{l}-7.72 \mathrm{E}-02 \\
(-4.16)^{* * *}\end{array}$ & $\begin{array}{l}-7.32 \mathrm{E}-02 \\
(-4.27) * * *\end{array}$ \\
\hline $\mathrm{C}$ & $\begin{array}{l}7.299 \\
(10.25) * * *\end{array}$ & $\begin{array}{l}6.18 \\
(7.9)^{* * *}\end{array}$ & $\begin{array}{l}4.336 \mathrm{E}-02 \\
(4.42)^{* * *}\end{array}$ & $\begin{array}{l}4.057 \mathrm{E}-02 \\
(4.29) * * *\end{array}$ \\
\hline $\mathrm{M}$ & $\begin{array}{l}2.267 \\
(14.808) * * *\end{array}$ & $\begin{array}{l}1.87 \\
(12.13)^{* * *}\end{array}$ & $\begin{array}{l}0.287 \\
(8.68) * * *\end{array}$ & $\begin{array}{l}0.276 \\
(8.62) * * *\end{array}$ \\
\hline $\mathrm{R}^{2}$ & 0.99 & 0.99 & 0.99 & 0.998 \\
\hline SEE & 758.03 & 107.8 & $5.033 \mathrm{E}-02$ & $4.760 \mathrm{E}-02$ \\
\hline F-statistics & 5290.4 & 2384.6 & 5999.00 & 1639.94 \\
\hline D-W & 2.17 & 1.81 & 1.63 & 1.60 \\
\hline
\end{tabular}

Note: Figures in (..) \& asterisks confer the same meanings as explained in Table 2

The regression results related to regular expenditure and its sub-factors indicate the fact that social services, communication and miscellaneous expenditures are found as the prominent factors to stimulate 
Impact of Annual Budgets in Economic Development of ..../11

the RE of Nepal in current and real price in linear form. Similarly, social services and miscellaneous expenditure is found less elastic to stimulate the RE of the country in current and real prices in log-linear form. Absence of serial correlation well justifies the models.

Table 5: Multiple Regression analyses (1974/75-2006/07)

\begin{tabular}{|c|c|c|c|c|c|c|c|c|}
\hline \multirow{2}{*}{\multicolumn{2}{|c|}{ Models }} & \multirow{3}{*}{$\begin{array}{c}\text { Dep. } \\
\text { Variabl } \\
\text { es } \\
\text { GDPag }\end{array}$} & \multicolumn{2}{|c|}{$\begin{array}{c}\text { Independent } \\
\text { Variables }\end{array}$} & \multirow{3}{*}{$\begin{array}{c}\mathbf{R}^{2} \\
0.53\end{array}$} & \multirow[t]{2}{*}{$\mathbf{F}$} & \multirow[t]{2}{*}{ SEE } & \multirow[t]{2}{*}{ D-W } \\
\hline & & & DE & RE & & & & \\
\hline 5.6 & $\begin{array}{l}\text { Log-Linear } \\
\text { (Nominal) }\end{array}$ & & $\begin{array}{l}0.85 \\
(2.5)^{* *}\end{array}$ & $\begin{array}{l}6.173 \mathrm{E}-2 \\
(0.264)\end{array}$ & & 16.7 & 0.27 & 1.45 \\
\hline 5.7 & $\begin{array}{l}\text { Log-linear } \\
\quad \text { (Real) }\end{array}$ & GDPag & $\begin{array}{l}1.24 \\
(4.6) * * *\end{array}$ & $\begin{array}{l}0.109 \\
(0.49)\end{array}$ & 0.54 & 17.64 & 0.26 & 1.54 \\
\hline 5.8 & $\begin{array}{c}\text { Linear } \\
\text { (Nominal) }\end{array}$ & GDPm & $\begin{array}{l}2.0 \\
(2.8) * * *\end{array}$ & $\begin{array}{l}3.51 \\
(9.96) * * *\end{array}$ & 0.95 & 267.7 & 2438.6 & 1.64 \\
\hline 5.9 & $\begin{array}{l}\text { Linear } \\
\text { (Real) }\end{array}$ & GDPm & $\begin{array}{l}1.24 \\
(1.86)^{*}\end{array}$ & $\begin{array}{l}3.55 \\
(11.14) * * *\end{array}$ & 0.83 & 71.53 & 1510.6 & 1.63 \\
\hline 6.1 & $\begin{array}{l}\text { Log-linear } \\
\text { (Nominal) }\end{array}$ & GDPm & $\begin{array}{l}0.36 \\
(3.14)^{* * *}\end{array}$ & $\begin{array}{l}0.628 \\
(8.24)^{* * *}\end{array}$ & 0.96 & 412.9 & $\begin{array}{c}9.287 \mathrm{E}- \\
02\end{array}$ & 1.45 \\
\hline 6.2 & $\begin{array}{l}\text { Log-linear } \\
\quad \text { (Real) }\end{array}$ & GDPm & $\begin{array}{l}0.48 \\
(4.13)^{* * *}\end{array}$ & $\begin{array}{l}0.64 \\
(10.0) * * *\end{array}$ & 0.85 & 86.1 & $\begin{array}{c}9.195 \mathrm{E}- \\
02\end{array}$ & 1.53 \\
\hline 6.3 & $\begin{array}{c}\text { Linear } \\
\text { (Nominal) }\end{array}$ & GDP & $\begin{array}{l}2.35 \\
(1.02)\end{array}$ & $\begin{array}{l}4.347 \\
(3.82)^{* * *}\end{array}$ & 0.67 & 34.6 & 34833.3 & 1.57 \\
\hline 6.4 & $\begin{array}{l}\text { Linear } \\
\text { (Real) }\end{array}$ & GDP & $\begin{array}{l}0.765 \\
(0.43)\end{array}$ & $\begin{array}{l}3.38 \\
(3.88) * * *\end{array}$ & 0.35 & 8.19 & 3833.2 & 1.64 \\
\hline 6.5 & $\begin{array}{l}\text { Log-linear } \\
\quad \text { (Real) }\end{array}$ & GDP & $\begin{array}{l}0.993 \\
(5.91)^{* * *}\end{array}$ & $\begin{array}{l}0.440 \\
(3.51)^{* * *}\end{array}$ & 0.75 & 44.82 & 0.15 & 1.44 \\
\hline 6.6 & $\begin{array}{c}\text { Linear } \\
\text { (Nominal) }\end{array}$ & GNP & $\begin{array}{l}4.361 \\
(10.73)^{* * *}\end{array}$ & $\begin{array}{l}6.709 \\
(33.87)^{* * *}\end{array}$ & 0.99 & $\begin{array}{c}3618 . \\
2\end{array}$ & 13103.1 & 1.49 \\
\hline 6.7 & $\begin{array}{l}\text { Linear } \\
\text { (Real) }\end{array}$ & GNP & $\begin{array}{l}2.32 \\
(4.38)^{* * * *}\end{array}$ & $\begin{array}{l}6.30 \\
(26.84) * * *\end{array}$ & 0.96 & $\begin{array}{c}461.0 \\
8\end{array}$ & 1632.5 & 1.82 \\
\hline 6.8 & $\begin{array}{c}\text { Linear } \\
\text { (Nominal) }\end{array}$ & PCI & $\begin{array}{l}0.145 \\
(1.40)\end{array}$ & $\begin{array}{l}0.121 \\
(2.36)^{* *}\end{array}$ & 0.564 & 19.37 & 1501.3 & 1.40 \\
\hline 6.9 & $\begin{array}{l}\text { Log-linear } \\
\text { (Nominal) }\end{array}$ & PCI & $\begin{array}{l}0.750 \\
(4.71)^{* * *}\end{array}$ & $\begin{array}{l}0.229 \\
(1.86)^{*}\end{array}$ & 0.833 & 74.61 & 0.14 & 1.51 \\
\hline 7.1 & $\begin{array}{l}\text { Log-linear } \\
\quad \text { (Real) }\end{array}$ & PCI & $\begin{array}{l}0.849 \\
(6.62) * * *\end{array}$ & $\begin{array}{l}0.282 \\
(2.21)^{* *}\end{array}$ & 0.837 & 77.14 & 0.13 & 1.64 \\
\hline
\end{tabular}

Note: Figures in (...) and asterisks confer the same meanings as explained in Table 1.2

The results of the log linear models with regard to the illustrated development indices conform the priori hypothesis that the development expenditure of Nepal during 1974/'75 to 2006/'07 assists to increase agricultural GDP at constant price by more than proportionately i.e. 124. Other than the agricultural GDP, all other development indices have shown less response. Similarly, regular expenditure seems to be 


\section{2 / Om Sharma}

more prominent factor to stimulate nominal manufactured GDP. An increase in regular expenditure (RE) brings about 4.3 units increase in nominal GDP. Despite of this, real manufactured GDP has been observed that has the incremental tendency through regular expenditure in linear modality. Nonetheless, DE could not be anticipated as a more prominent factor to stimulate the real GDP because 100 per cent increase in DE leads only to 99 per cent increase in it. Both the expenditures however are major determining factors as evidenced by linear model in the nominal and real GNP of the country. The above findings indicate 1 percent additional amount of RE leads to increase GNP by more than 6.3 per cent. The coefficients of DE (85\%) both at current and constant prices are greater than that of the coefficients of RE (28\%) in the log-linear form of model. Thus, more funds are to be diverted for new development projects on agriculture.

As a supportive model, annual budget (DE and RE) has also been treated together with foreign aid, internal loan and internal revenue through which the prominent factor in determining the annual budget has sought. In this regard, foreign aid, internal loan and internal revenues are further brought under discussion and only the reliable and significant results free from serial correlation, significant at 1 to 10 percent level and having high degree of association, are included. Foreign aid is the major factor in determining the nominal and real development expenditure. One per cent increase in foreign aid (FA) helps increase the nominal and real development expenditure by 1.69 and 1.41 percent, respectively. Foreign aid is seen more responsive to stimulate the real DE of the country on the contrary; internal revenue works negatively and reduces $\mathrm{DE}$ by 16 to 18 percent but raises regular expenditure by 121 per cent.

Table 6 : Multiple Regression Results 1974/75-2006/07

\begin{tabular}{|c|c|c|c|c|c|c|c|c|}
\hline \multirow[t]{2}{*}{ Models } & \multirow{2}{*}{$\begin{array}{l}\text { Dep. } \\
\text { Vari. }\end{array}$} & \multicolumn{7}{|c|}{$\begin{array}{c}\text { Independent } \\
\text { Variables }\end{array}$} \\
\hline & & FA & IL & IR & $\mathbf{R}^{2}$ & $\mathbf{F}$ & SEE & D-W \\
\hline $\begin{array}{l}\text { 7.2 Linear } \\
\text { (Nominal) }\end{array}$ & $\mathrm{DE}$ & $\begin{array}{l}1.69 \\
(9.28)^{* * *}\end{array}$ & $\begin{array}{l}0.662 \\
(2.0)^{*}\end{array}$ & $\begin{array}{l}-0.178 \\
(-2.3)^{* *}\end{array}$ & 0.94 & 147.8 & 1974.9 & 1.43 \\
\hline $\begin{array}{l}\text { 7.3 Linear } \\
\text { (Real) }\end{array}$ & $\mathrm{DE}$ & $\begin{array}{l}1.41 \\
(8.62)^{* * *}\end{array}$ & $\begin{array}{l}0.503 \\
(2.3) * * *\end{array}$ & $\begin{array}{l}-0.157 \\
(-3.0) * * *\end{array}$ & 0.76 & 31.1 & 270.59 & 1.47 \\
\hline $\begin{array}{l}\text { 7.4 Linear } \\
\text { (Real) }\end{array}$ & RE & $\begin{array}{l}3.763 \mathrm{E}-02 \\
(0.19)\end{array}$ & $\begin{array}{l}-6.73 E-02 \\
(-0.30)\end{array}$ & $\begin{array}{l}0.816 \\
(12.4)^{* * *}\end{array}$ & 0.89 & 81.2 & 270.72 & 1.48 \\
\hline $\begin{array}{l}\text { 7.5 Log- } \\
\text { linear } \\
\text { (Nominal) }\end{array}$ & $\mathrm{RE}$ & $\begin{array}{l}6.642 \mathrm{E}-03 \\
(0.76)\end{array}$ & $\begin{array}{l}6.053 \mathrm{E}-02 \\
(1.46)\end{array}$ & $\begin{array}{l}0.977 \\
(12.2)^{* * *}\end{array}$ & 0.98 & 733.4 & $\begin{array}{l}8.138 \mathrm{E}- \\
02\end{array}$ & 2.14 \\
\hline $\begin{array}{l}\text { 7.6 Log- } \\
\text { linear } \\
\text { (Real) }\end{array}$ & $\mathrm{RE}$ & $\begin{array}{l}\text { 5.602E-02 } \\
(0.73)\end{array}$ & $\begin{array}{l}5.431 \mathrm{E}-02 \\
(1.3)\end{array}$ & $\begin{array}{l}1.210 \\
(18.2)^{* * *}\end{array}$ & 0.97 & 348.4 & $\begin{array}{l}8.433 \mathrm{E}- \\
02\end{array}$ & 1.88 \\
\hline
\end{tabular}

Note: Figures in parentheses and asterisks confer the same meaning as explained in Table 1.2

The results of the study are in line with the findings of most developing countries. It is because aid is mainly given for development expenditure and development projects are of longer duration and once commenced, can not be abandoned. It implies that the longer the development projects, the larger will be 
Impact of Annual Budgets in Economic Development of ..../13

the aid. Thus, from the above results it is realized that without using the assistance of Foreign Aid (FA), Nepalese economy may become less effective in development activities. Bhattrai (2007) too finds the similar strong relationship between Foreign aid and Development Expenditure based on the database of FY 1975 to 2002.

\section{CONCLUSION AND SUGGESTIONS}

Developing countries have adopted government budgetary system as a tool to accelerate the pace of economic development and annual budget is considered sine-quo-non of the modern government. The budgetary process is widely accepted as an efficient strategy to accomplish the development goals of the nation. The concept of effect of annual budget implies the supply side of the development process.

At the course of trend analysis, the various variables have been brought to examine the macro pattern. Among these variables agricultural GDP, manufactured GDP, total GDP, GNP, PCI are taken as the macro development indicators along with capital formation. The trend of DE, RE, TE and its GDP ratio have been found satisfactory. The planning mechanism in the country has been substantially noneffective and therefore it is necessary to fix the targets on the basis of empirical programs rather than on the basis of ad-hoc decisions. In fulfilling the objectives and targets, since institutional factors play critical role policies have to be simultaneously evolved in reforming institutions in order to implement programs effectively. It is necessary to envisage the projects and programs in conformity with the production targets in a more operational and more realistic way. In view of the major chunk of internal resources primarily utilized in financing consumption type of expenditures, it is equally necessary to standardize the project planning. Though foreign aid is an exogenous and externally determining factor, a part of it goes towards non-productive consumption activities; its utilization pattern has to be drastically corrected. The overriding trend on regular expenditure reflects alarming situation with regard to fiscal discipline and the overall development program of the country. The government should establish an appropriate environment to open the various sectors for private investment. A nominal role of internal borrowing and internal revenue in the economy and the excessive dependence on foreign aid has led the country for heavy debt service obligations every years forcing for additional tax burden. Therefore, other domestic sources mobilization prospects and opportunities should be sought with full venture by the government. The development activities are highly influenced by the open border of neighboring countries. Therefore, it is necessary to introduce some control measures on the borders between two countries in the larger economic interests of the country and people.

\section{REFERENCES}

Bhattrai, Badri Prasad (2007). Foreign Aid and Government's Fiscal Behaviour in Nepal: an Empirical Analysis. Australia : School of Economics and Finance, University of Western Sydney Parramatta.

Chaudhary, R.K. (1996). Public Finance and Fiscal Policy. New Delhi : Kalyani Publication.

Hajela, T.N. (2001). History of Economic Thought. (15 ${ }^{\text {th }}$ revised edition). Delhi : Konark Publishers Pvt. LTD.

Higgins, Benjamin (1999). Economic Development, New Delhi : Universal Book Stall. 
Khanal, D.R. (1988). Public Expenditure in Nepal; Growth Pattern and Impact. New Delhi : Sterling Publishers (P) LTD.

Khanal, Prem (2005). An Analysis of Public Expenditure in Nepal Economic Reforms and Democracy in Nepal: A case study of Government Plans, Programs and Budget Affecting Children in Nepal. New Mexico : Nepal Study Center, the University of New Mexico.

Lekhi, R.K. (2006). Public Finance. $13^{\text {th }}$ edition. Ludhiana : Kalyani Publishers House.

MoF (2006). Budget Speech 2006/07. Kathmandu : Author.

MoF (2008). Economic Survey FY 2007/08, Kathmandu : Author.

Pyakuryal, B. (2004). Nepal's Conflict Economy: Cost Consequences and Alternatives. Kathmandu : Nepal Economic Association.

Shrestha, B.P. (1990). Nepalese Economy in Retrospect and Prospect. Kathmandu : Himalayan Book Seller.

Singh, S.K. (1977). The Fiscal System of NepaL. First edition. Kathmandu : Ratna Pustak Bhandar.

Sharma, Bishnu Prasad (1999). "The Problems and Prospects of Regular and Developmental Budget of HMG / Nepal." The Economic Journal of Nepal, vol 22 (1) : 1-17.

Sharma, Om (2001). Tourism Development and Planning in Nepal, Thesis Submitted for the Degree of $\mathrm{Ph}$. D. in Economics Baranas Hindu University, India.

Todaro, M.P. (1997). Economic Development (Sixth edition). London : Addison Wesley Longman Limited.

WB (2009). World Development Report 2008. Washington DC : World Bank. 